\title{
EXPERIMENTAL STUDY ON INFECTIVE ENDOCARDITIS IN DOGS: REFERENCE TO CLINICO-PATHOLOGICAL AND ECHOCARDIOGRAPHIC EXAMINATION
}

\author{
Naglaa A. Gomaa ${ }^{a}$., Noha A. Beder ${ }^{b}$ and Mahmoud A. Allaam ${ }^{C}$. \\ a Department of Animal Medicine. Faculty of Veterinary Medicine, \\ Kafr Elsheikh University. \\ b Department of Animal Medicine. Faculty of Veterinary Medicine, \\ Damanhour University. \\ c Department of Animal Medicine and Infectious Diseases. Faculty of Veterinary \\ Medicine, Sadat City University.
}

\begin{abstract}
This study was carried out on 10 dogs that were subjected to experimentally-induced bacterial endocarditis. All the examined dogs were used as a control group before the induction of the experiment. The dogs with induced endocarditis showed wide variety of manifestations including fever, anorexia, decrease skin tugor, heavy panting, coughing, tremors at cardiac area, and loss of reflexes. Auscultation of the heart revealed the presence of valvular murmurs. The hematological examination proved a significant increase in WBCs count, PCV\%, and neutrophil\%. On the other hand, a significance decrease in lymphocyte\%, $\mathrm{Hb}$ and RBCs count were recorded. Two dimension echocardiography showed a nodular hyperechoic structure attached to the anterior leaflet and the wall of left atrium proximal to septal leaflet of the mitral valve which representing the bacterial vegetation. Besides the enlargement of left ventricular diameter which is also characteristic to infective endocarditis. By M-mode, the diastolic flutter of the anterior mitral valve leaflets and premature
\end{abstract}


closure of mitral valve are distinctive to endocarditis. At necropsy, the heart revealed the presence of cauliflower-like masses that considerably reduced the size of the valvular orifice in some cases. Histological examination revealed the presence of acute valvulitis, coronary thrombosis and bacterial colonies.

This study aimed to throw a light on the early stages of pathological alterations associated with bacterial endocarditis in dogs.

Key words: dogs- experimental endocarditis- echocardigraphy

\section{INTRODUCTION}

Infective endocarditis (IE) is a bacterial disease that affects the inner layer of the heart and involves the heart valves, interventricular septum, the chordae tendineae and the mural endocardium. It is uncommon but often fatal disease of dogs (MacDonald et al., 2004). Prevalence of endocarditis in dogs ranged from $0.04 \%$ to $0.58 \%$ (Lombard and Buergelt, 1993; Buchanan, 1999). Incidence increases with advancing age, males and large breed are at greater risk for infection.Staphylococcus spp.,Streptococcus spp., E. coli, Corynebacterium and Bartonella spp. are the most common bacterial isolates from dogs with infective endocarditis (Calvert, 1982; Sisson and Thomas., 1984; MacDonlad, 2010).

Bacteremia either persistent or transient is necessary for an endocardium infection while it is not the only cause of endocarditis. There are many predisposing factors that might contribute such as bacterial virulence, immune system abnormalities or inherited factors (Kittleson and Kienle, 1998). Although a variety of bacteria can be isolated with routine blood cultures, Streptococci were the most common 
cause of infective endocarditis in dogs and were more likely to infect the mitral valve and be associated with polyarthritis (MacDonlad, 2010). The mitral valve is most commonly affected, followed by the aortic valve while the tricuspid and pulmonic valves are rarely affected (Kittleson and Kienle, 1998).

It presents many challenges with respect to diagnosis of infective endocarditis in dogs depending on clinical presentation as there are variety of signs appear on affected dog. A presumptive diagnosis of infective endocarditis is made based on the positive findings of more than two blood cultures (Peddle and Sleeper, 2007). In addition to echocardiographic examination which depend on the presence of vegetation or valvular damage which is a characteristic feature of endocarditis (Kittleson and Kienle, 1998).

The present study aimed to investigate the early stages of pathological alterations associated with experimental Staphylococcal endocarditis in dogs based on the clinical manifestations and hematological alterations in addition to the echocardographic evidences.

\section{MATERIAL AND METHODS}

\section{Animals:}

Ten stray dogs aged between 3 to 9 months old and weight ranged from 10-16 kg were kept individually in steel cages and fed on a diet composed of meat, bones and bread adlibtum for 6 weeks before experiment. They were subjected to complete deworming by injection of $0.5 \mathrm{ml}$ of Ivermectin $1 \%$ S.C and repeated after 3 weeks with continues disinfecting the cages. 


\section{Experimental endocarditis:}

Experimental endocarditis was induced based on the previously described technique with some modifications (Nicolau et al. 1996), after approving of the Veterinary Trial Commission, Faculty of veterinary medicine, Menoufia University, Egypt. Briefly, the animals were anesthetized, then injected intracardiac by $1 \mathrm{ml}$ of broth-starch mixture containing Staphylococcus aurus at the left side between the fourth and fifth ribs. The length of the needle was too long to reach left ventricle through the skin. The needle must be moved with each pulsation of the heart and the blood must flow throw the needle before injection of the broth. All dogs were evaluated by clinical, laboratory and echocardiographic examinations before and then after 1, 2, 3 and 4 days of injection.

\section{Clinical and hematological examination:}

A complete physical examination including measurement of body temperature, pulse and auscultation of heart was applied before and during the period of experiment (Kelly, 1984). In addition to hematological examination includes RBCs, WBCs, Hb, PCV and differential leukocytic count was performed (Coles, 1986).

\section{Echocardiographic examinations:}

Echocardiographic examinations were performed using a real time B- mode and M- mode ultrasound System (B7v veterinary multi-purpose ultrasound scanner Noveko Company, made in Canada). The examination was performed using $4 \mathrm{MHz}$ convex transducer. A black and white video graphic printer (890 MD Sony $\backslash \circledR)$ was used for printing 
the frozen image. In preparation for the echocardiographic examination, the area from 3rd to $6^{\text {th }}$ ribs on both sides of the thorax was clipped, shaved and swabbed with alcohol to remove excess oil, and coupling gel was applied. The third, fourth and fifth intercostal spaces in the cardiac region were examined ultrasonographically on the right and then the left sides of the thorax. The thoracic limbs were moved cranially to facilitate better contact between the probe and the intercostal space (Gomaa, 2004).

\section{Macroscopic and microscopic examinations:}

Heart of each slaughtered dog was carefully examined by naked eye for detection of any gross lesions at the end of the experiment. Following complete necropsy sacrificed animals; fresh specimens were collected for histopathological examination (Culling, 1983).

\section{Statistical analysis:}

The data were analyzed by using one-way analysis of variance (ANOVA) (Norman and Baily 1997)

\section{RESULTS}

\section{Clinical findings:}

Signs of systemic diseases were variable and include extreme weakness, depression, fever, anorexia, decrease skin tugor, heavy panting, weight loss and dehydration. Cardiac signs included tremors at cardiac region, cold extremities, loss of reflexes, nocturnal cough, dyspnea, and the presence of variation in heart sounds by auscultation which includes systolic vulvular murmurs. Clinical examination of the 
infected dogs showed significant increase $(p<0.05)$ in the body temperature, pulse and respiratory rates at the $1^{\text {st }}$ day $(p<0.05)$ post injection of broth-starch mixture containing Staphylococcus aurus and begin to increase gradually to reach its maximum at $4^{\text {th }}$ day after injection. The mucous membrane was pink before the injection and became congested till the $4^{\text {th }}$ day of the experiment; it converted to cyanosed (Table 1).

Table (1): Body temperature, Pulse, Respiratory rates and mucous membrane of dogs with induced bacterial endocarditis (Mean \pm S.E).

\begin{tabular}{|c||c||c||c||c||}
\hline \multirow{2}{*}{ Time(day) } & $\begin{array}{c}\text { Body temperature } \\
\text { (c) }\end{array}$ & $\begin{array}{c}\text { Pulse rate } \\
\text { (Beat/min) }\end{array}$ & $\begin{array}{c}\text { Respiratory rate } \\
\text { (cycle/min) }\end{array}$ & $\begin{array}{c}\text { Mucous } \\
\text { Membrane }\end{array}$ \\
\hline \hline $\mathbf{0}$ & $38.1 \pm 0.054^{\mathrm{d}}$ & $78.5 \pm 0.005^{\mathrm{e}}$ & $17.2 \pm 0.031^{\mathrm{e}}$ & Pink \\
\cline { 2 - 5 } & $39.2 \pm 0.002^{\mathrm{c}}$ & $94.2 \pm 0.13^{\mathrm{d}}$ & $32.5 \pm 0.042^{\mathrm{d}}$ & Congested \\
\cline { 2 - 5 } & $40.0 \pm 0.03^{\mathrm{bc}}$ & $100.2 \pm 0.054^{\mathrm{c}}$ & $36.5 \pm 0.007^{\mathrm{c}}$ & Congested \\
\hline $\mathbf{1}$ & $40.2 \pm 0.061^{\mathrm{b}}$ & $105.2 \pm 0.041^{\mathrm{b}}$ & $39.8 \pm 0.006^{\mathrm{b}}$ & Congested \\
\hline $\mathbf{2}$ & $41.5 \pm 0.12^{\mathrm{a}}$ & $110.5 \pm 0.051^{\mathrm{a}}$ & $52.4 \pm 0.009^{\mathrm{a}}$ & Cyanosed \\
\hline $\mathbf{4}$ & & &
\end{tabular}

A,b,c,d: Means within the same column having the different letters are significantly different at $(\mathrm{P}<0.05)$.

\section{Hematological findings:}

The mean values of WBCs count, neutrophils \% and PCV\% were significantly $(p<0.05)$ increased at $1^{\text {st }}$ day post injection, then increased gradually to reach their maximal values at the $4^{\text {th }}$ day post injection while the mean values of lymphocyte\%, Hb content and RBCs count were significantly $(p<0.05)$ decreased at $1^{\text {st }}$ day post injection, then decreased gradually to reach their minimal value at the $4^{\text {th }}$ day post injection (Tables 2 and 3). At the same time, the mean value of eosinophil \% and monocyte\% were not significantly affected during the experiment (Table 3).

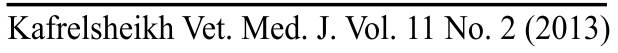


Table (2): Hematological picture of dogs with induced bacterial endocarditis (Mean \pm S.E).

\begin{tabular}{|c||c||c||c||c||}
\hline Time(day) & PCV\% & Hb g/dl & RBCs million/mm & $\begin{array}{c}\text { WBCs } \\
\text { Thousand/ } \mathbf{~ m m}^{\mathbf{3}}\end{array}$ \\
\hline \hline $\mathbf{0}$ & $35.01 \pm 0.21^{\mathrm{e}}$ & $13.10 \pm 0.17^{\mathrm{a}}$ & $7.06 \pm 0.12^{\mathrm{a}}$ & $10.21 \pm 0.06^{\mathrm{e}}$ \\
\hline $\mathbf{1}$ & $37.27 \pm 0.34^{\mathrm{d}}$ & $13.06 \pm 0.15^{\mathrm{b}}$ & $6.82 \pm 0.10^{\mathrm{b}}$ & $11.76 \pm 0.35^{\mathrm{d}}$ \\
\hline $\mathbf{2}$ & $40.31 \pm 0.21^{\mathrm{c}}$ & $12.48 \pm 0.25^{\mathrm{c}}$ & $6.46 \pm 0.003^{\mathrm{c}}$ & $12.78 \pm 0.23^{\mathrm{c}}$ \\
\hline $\mathbf{3}$ & $42.42 \pm 0.07^{\mathrm{b}}$ & $12.21 \pm 0.08^{\mathrm{d}}$ & $6.25 \pm 0.13^{\mathrm{d}}$ & $13.90 \pm 0.17^{\mathrm{b}}$ \\
\hline $\mathbf{4}$ & $45.81 \pm 0.01^{\mathrm{a}}$ & $12.01 \pm 0.02^{\mathrm{e}}$ & $5.95 \pm 0.005^{\mathrm{e}}$ & $14.69 \pm 0.16^{\mathrm{a}}$ \\
\hline
\end{tabular}

A,b,c,d: Means within the same column having the different letters are significantly different at $(\mathrm{P}<0.05)$.

Table (3): Differential leukocytic count of dogs with induced bacterial endocarditis (Mean \pm S.E).

\begin{tabular}{|c|c|c|c|c|}
\hline Time(day) & N\% & L\% & M\% & E\% \\
\hline 0 & $58.0 \pm 0.05 \mathrm{e}$ & $35.33 \pm 0.88 \mathrm{e}$ & $3.67 \pm 0.03 a$ & $2.0 \pm 0.0 \mathrm{a}$ \\
\hline 1 & $62.67 \pm 0.42 \mathrm{~d}$ & $31.67 \pm 1.20 \mathrm{~d}$ & $3.27 \pm 0.33 a$ & $2.0 \pm 0.0 \mathrm{a}$ \\
\hline 2 & $66.67 \pm 1.06 \mathrm{c}$ & $27.33 \pm 1.33 \mathrm{c}$ & $3.03 \pm 0.12 \mathrm{a}$ & $2.0 \pm 0.0 \mathrm{a}$ \\
\hline 3 & $69.67 \pm 0.05 b$ & $24.0 \pm 1.41 \mathrm{~b}$ & $3.13 \pm 0.23 a$ & $2 \pm 0.0 \mathrm{a}$ \\
\hline 4 & $73.67 \pm 0.12 \mathrm{a}$ & $20.0 \pm 1.53 a$ & $3.67 \pm 0.14 \mathrm{a}$ & $2 \pm 0.33 a$ \\
\hline
\end{tabular}

A,b,c,d: Means within the same column having the different letters are significantly different at $(\mathrm{P}<0.05)$.

\section{Echocardiographic examinations:}

Standard echocardiographic views of the heart were taken by 2-D mode and M- mode as previously described (Gomaa, 2004). In the control group, the right parasternal short and long axis views were taken. In which, the interventricular septum, mitral and tricuspid valves were well visualized (Fig.1a). The echocardiographic findings in infective vegetative endocarditis were distinctive. A nodular distortion on mitral valve leaflets which represent the vegetation of bacteria was readily apparent as hyperechoic thickening of anterior and septal leaflets of the mitral valve; in addition to the presence of enlargement of left ventricle at the end of the experiment (Fig. 1b). M-mode examination also revealed diastolic flutter of the anterior mitral valve leaflet and premature closure of mitral valve (Fig 2).

Kafrelsheikh Vet. Med. J. Vol. 11 No. 2 (2013) 
Naglaa A. Gomaa et., al.
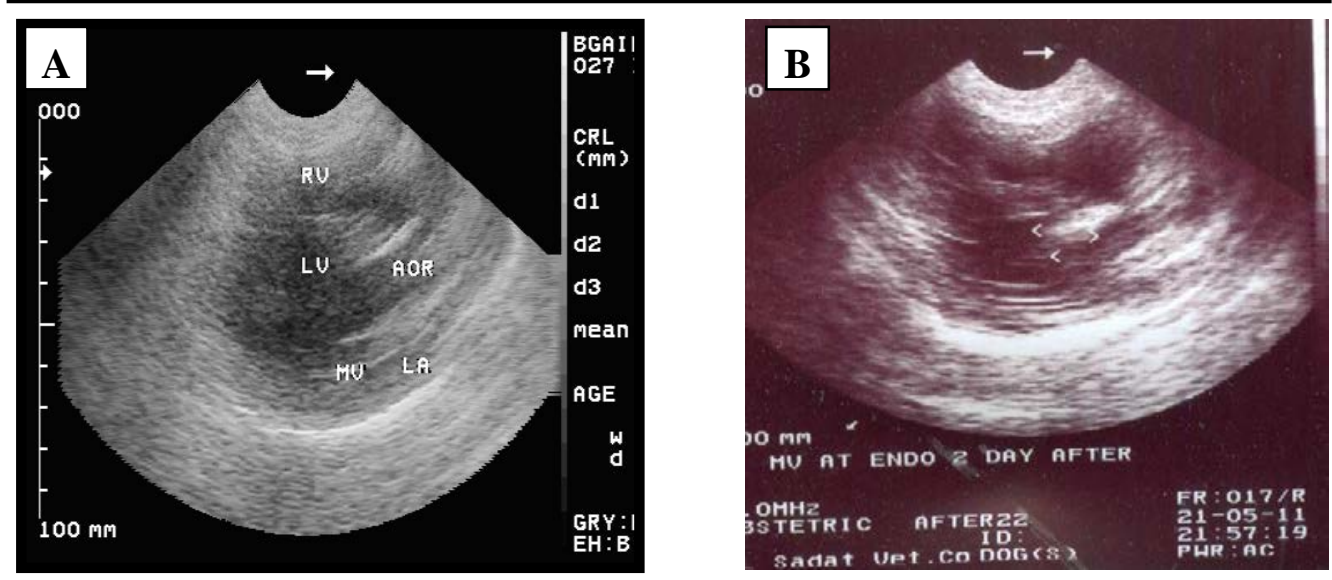

Fig. (1): (A) Echocardiographic of right Parasternal long-axis left ventricular outflow view normal heart before the experiment by $4 \mathrm{MHz}$ probe. $\mathrm{LV}=$ left ventricle, $\mathrm{LA}=$ left atrium, $\mathrm{RV}=$ right ventricle, $\mathrm{RA}=$ Right atrium and $\mathrm{AO}=$ aorta root; $(\mathrm{B})$ Echocardiographic of heart with long axis view showing large hyperechoic structure associated to anterior leaflet of the mitral valve represent vegetative lesion at diastole.

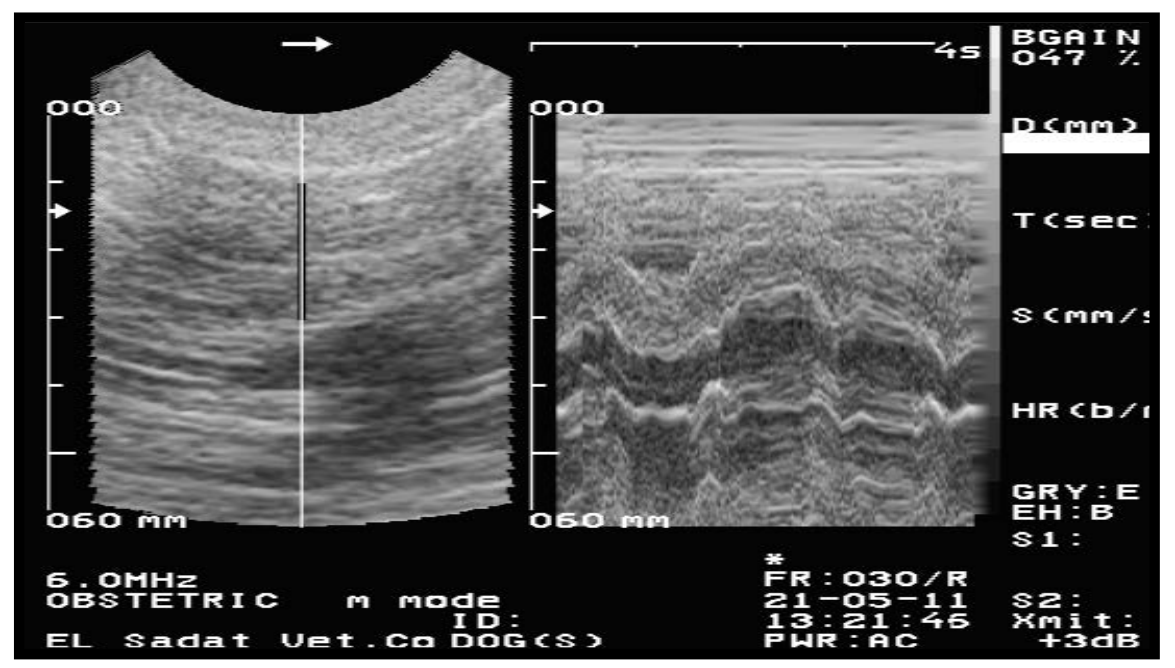

Fig. (2): M-echocardiogram obtained at Mitral valve leaflet showing diastolic flutter of the anterior mitral valve leaflet and premature closure of mitral valve using $4 \mathrm{MHz}$ convex transducer.

$\overline{\text { Kafrelsheikh Vet. Med. J. Vol. } 11 \text { No. } 2 \text { (2013) }}$ 


\section{Pathological findings:}

Macroscopically, the heart of dogs after 4 days post-injection revealed the presence of bacterial vegetation which form cauliflower-like masses of variable size with broad bases and sometimes could considerably reduce the size of the valvular orifice. The valves were edematous and petechiated. The heart muscle were congested and spotted with hemorrhages. Subendocardial ecchymoses especially at the site of papillary muscle and subepicardial petechiae had be seen (Figs 3,4,5).

Microscopically,acute valvulitis was evidenced by an accumulation of neutrophils and the presence of severe edema of the valves. The myocardium showed diffuse or local cellular infiltration and intact extravasated RBCs between cardiac muscles as well as thrombosis and zenker necrosis were noticed in myocardium. Staining a thin film with a crystal violet stain showed clumps of bacteria (Figs 6,7,8,9).

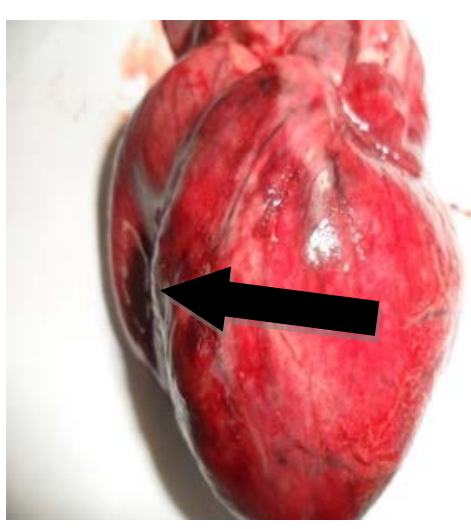

Fig. (3): The gross lesion of heart appear with subepicardial petechiae are seen (black arrow).

$\overline{\overline{\text { Kafrelsheikh Vet. Med. J. Vol. } 11 \text { No. } 2 \text { (2013) }}}$

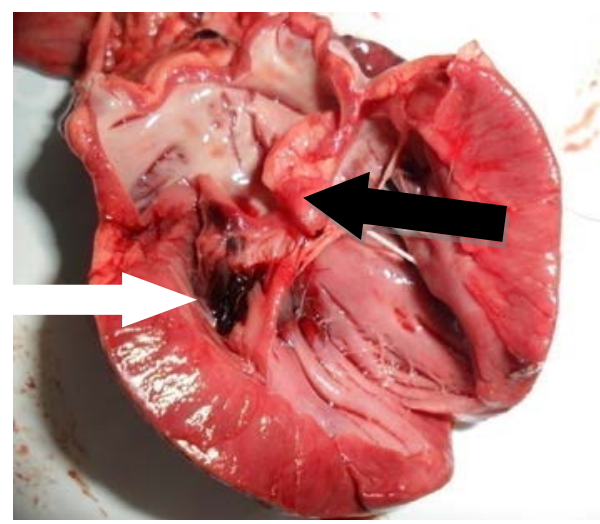

Fig. (4): Cauliflower-like masses of variable size of vegetative lesions appear on the edge of the anterior mitral valve leaflet (black arrow). The valve appear swollen and edematous (white arrow). 
Naglaa A. Gomaa et., al.

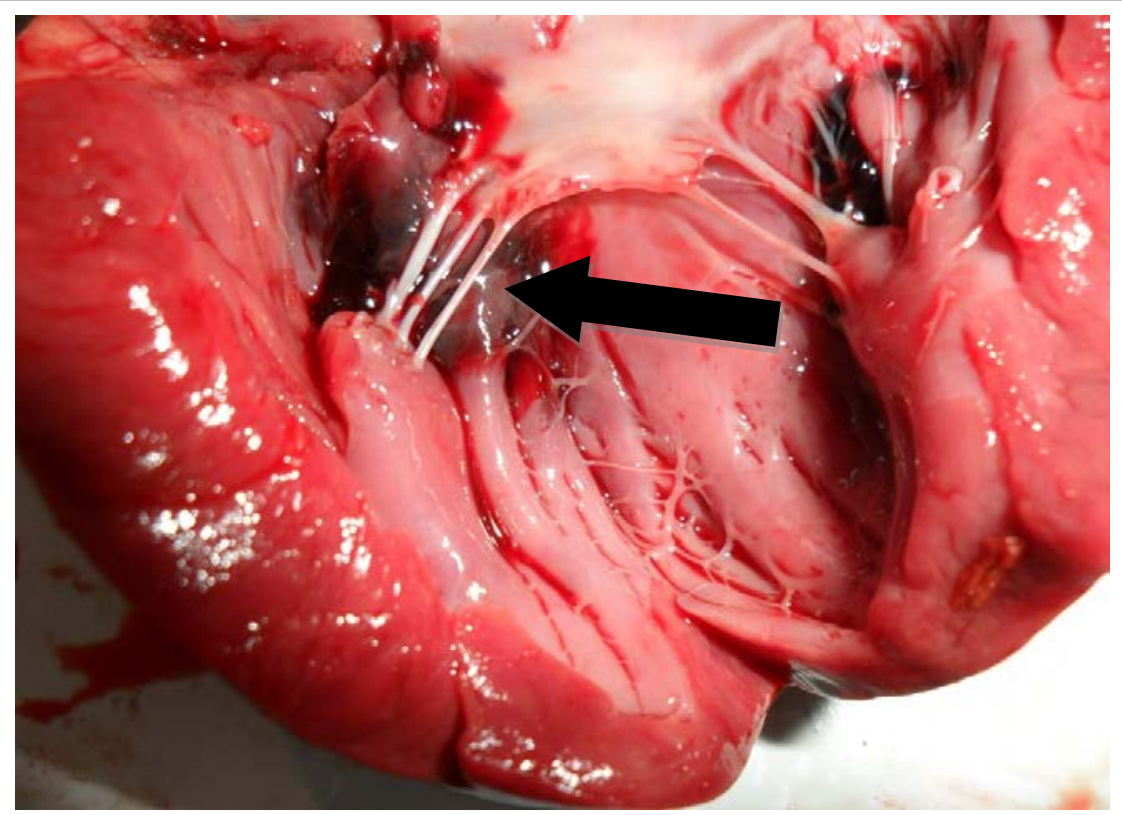

Fig. (5): The heart muscle are congested and spotted with hemorrhages. Subendocardial ecchymoses especially at the site of papillary muscle. (black arrow)

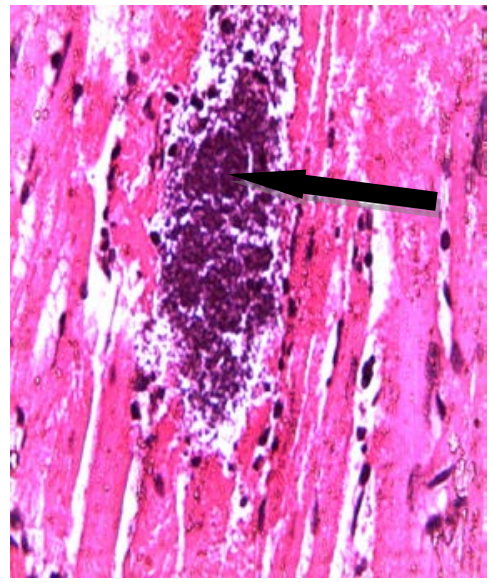

Fig. (6): Vegetative endocarditis shows bacterial colonies attached to myocardium (black arrow) by $\mathrm{H} \& \mathrm{E}$ X20

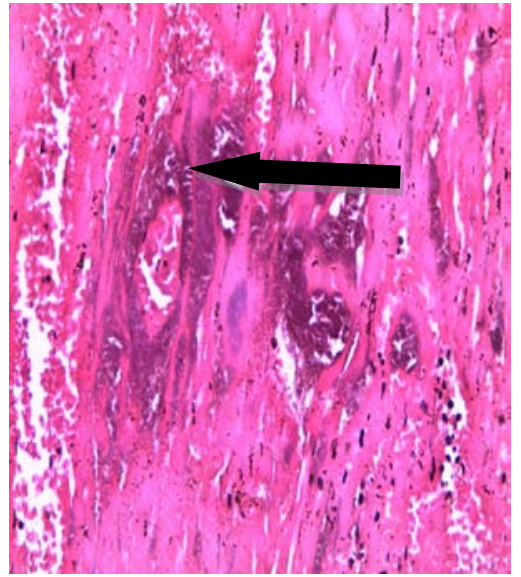

Fig. (7): Vegetative endocarditis shows Zenker necrosis (black arrow) by H\&E X20

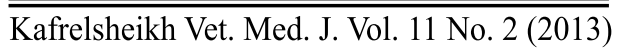




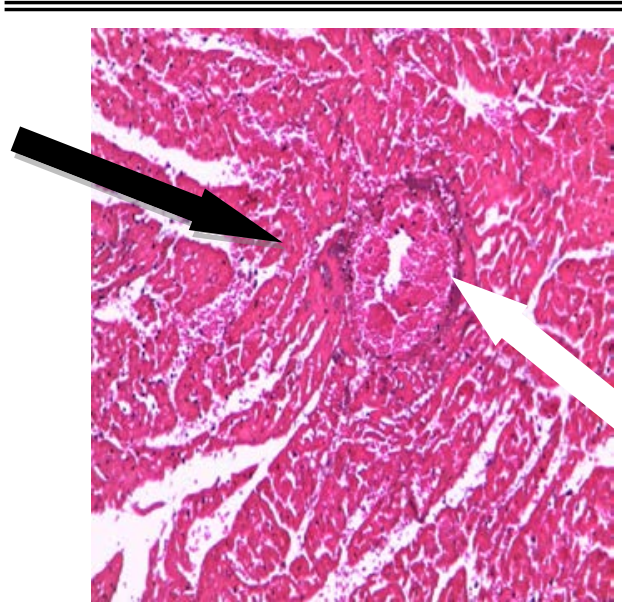

Fig. (8): Show intact extravasated RBCs between cardiac muscle (black arrow) and presence of thrombosis (white arrow) by H\&E X10

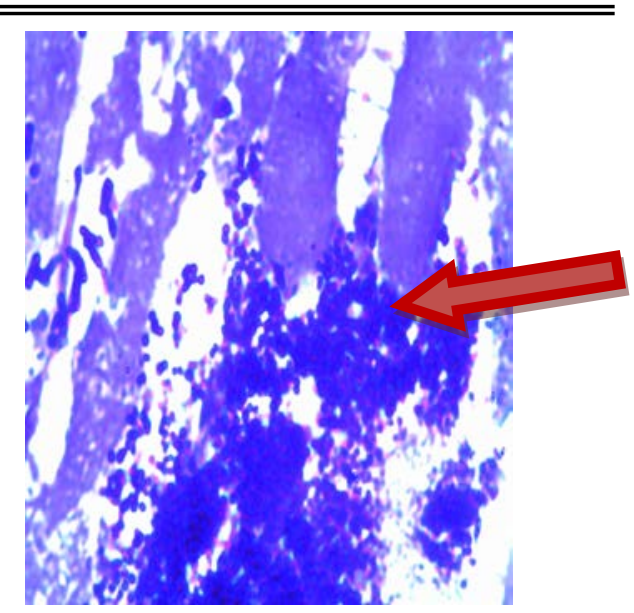

Fig. (9): A thin film stained by crystal violet stain showed clumps of staphylococcus bacteria (red arrow) X10

\section{DISCUSSION}

A variety of bacteria cause bacterial endocarditis in dogs (MacDonald et al., 2004). There was a relationship between the type of infective bacteria and the clinical manifestations appeared on dogs with infective endocarditis (Sykes et al., 2006). In this study, dogs with induced staphylococcal endocarditis showed wide range of clinical manifestations which reflects the wide spectrum of the disease. This could be attributed to the release of bacteria from infected valves into the circulation and infect other organs including cardiovascular, nervous, digestive, urinary, reproductive systems, and joints (Kittleson and Kienle, 1998). In the present study, all examined dogs had fever and cardiac murmur as signs of acute infection. Fever and cardiac murmur were often detected on the initial examination of dogs with infective 
endocarditis (Sykes et al., 2006; Allaam 2012). Some other previous studies which did not detect fever on examined dogs with infective endocarditis has been attributed that to the effect of antimicrobical therapy, advancing age, uremia, congestive heart failure (CHF) and prolonged period of infection (Bayer and Scheld, 2000; Calvert and Wall, 2006). The cardiac murmurs were systolic as a result of vegetation and damage of mitral or aortic valves causing vulvular regurgitation or stenosis. The mitral valve is the most commonly affected valve in the heart with bacterial endocarditis because of the traumatic injury of the valve due to the high systolic pressure on it (Kittleson and Kienle, 1998). This traumatic injury probably results in very minute damage to the endothelial surfaces of the valves which can be colonized by circulating bacteria. This may explain why the mitral valves are more prone to infective endocarditis (Kittleson and Kienle, 1998).

The most clinicopathological alterations in hemogram are related to sepsis. Leukocytosis and hypoalbuminemia are more common laboratory abnormalities in dogs with infective endocarditis similar to perivous studies (Sykes et al., 2006; Calvert and Wall, 2006). The increase in WBCs might be attributed to acute bacterial infection, in which white blood cells produce a substance known as the colony-stimulating factor (CSF), which stimulates the bone marrow to increase the white blood cell production and stimulate mobilization of neutrophils into the peripheral circulation which can be doubled within a few hours (Pauksen et al., 1994). Moreover, the gradual increase of PCV\% may be attributed to dehydration resulting from hypoalbuminemia as reported by previous studies (Breitschwerd et al., 1999; Sykes et al., 2006). 
On the other hand, the significant decrease in $\mathrm{Hb}$ and RBCs count were approved anemia. Non-regenerative, normocytic, normochromic anemia is the most commonly reported clinicopathological changes in infective endocarditis in dog and human (Heffner, 1979). This may attributed to immune mediated hemolytic anemia (Means Jr., 2000). In addition to lymphocytopenia which accompanied neutrophila and this have been suggestive of bacteremia (Wyllie et al., 2004).

Echocardiographic visualization of characteristic valvular lesions in dogs is easier than in human due to the favorable thoracic anatomy of dog (Kittleson and Kienle, 1998). The changes in echocardiographic picture by 2D and M-mode examinations of infective vegetative endocarditis was attributed to the presence of nodular vegetative bacteria on the valve leaflet which appeared as hyperechoic structure lead to the alteration of valvular closure. These findings were previously recorded by (Kim et al., 1989; Mylonakis and Calderwood, 2001).

Macroscopically, the bacterial vegetation on the valve leaflet appeared as cauliflower-like masses of variable size and sometimes could considerably reduce the diameter of the valvular orifice. Myocardium especially at papillary muscles and valves were congested and spotted with petechia. Similar findings were previously recorded by (Miller et al., 2004; Mylonakis and Calderwood, 2001; Thiene and Basso, 2006).

Histopathological evaluation of necropsy specimen revealed the presence of acute valvulitis, endocardial heamorrghe and cellular infiltration; in addition to bacterial colonies and coronary thrombosis. Similar findings were previously recorded by (McGavin et al., 2004; Miller et al., 2004; Thiene and Basso, 2006). 
Finally, it could be concluded that, the diagnosis of canine staphylococcal endocarditis is usually based on appropriate clinical manifestations as well as clinicopathological alterations and confirmed by distinctive echocardiographic findings or typical pathologic lesions.

\section{REFERENCES}

- Allaam M. A. (2012): Diagnostic studies of chest affections among pet animals with special references to ultrasonography. Ph D. Thesis in veterinary internal medicine. Sadat city University.

- Bayer AS and Scheld WM (2000): Endocarditis and intravascular infection. In: Mandell GL, Bennett JE, Dolin R, eds. Mandell, Doughlas and Bennett. Principles and practice of infectious disease 5th ed. Philadelphia: Churchill livingstone, 867-902.

- Breitschwerd BW, Clarke EA, Browen TT, Kordick LD and Snyder SP (1999): Bartonella Vinsonil subsp. Berkhoffi and related members of alpha subdivision of proteobacteria in dogs with cardiac arrythemia, endocarditis or myocarditis.J.Clinic Microbiology;37(11): 3618-3626.

- Buchanan J.W (1999): Prevalence of cardiovascular disorders. In Fox PR, Sisson DD, Moïse NS ed. Textbook of canine and feline cardiology, 2nd ed. Philadelphia, WB Saunders; 457-470.

- Calvert CA (1982): Valvular bacterial endocarditis in the dog. J. Am. Vet. Med. Assoc; 1080-1084.

- Calvert C and Wall M (2006): Cardiovascular infectious diseases of dog and cat. St. Louis: Saunders Elevier; 841-865.

- Coles HE (1986): "Veterinary Clinical Pathology" 4th Ed., Philadelphia, London, Toronto, Tokyo, Sydney, Hong Kong.

- Culling CF (1984): "Handbook of Histopathological and Histochemical Techniques" 3rd Ed., Butterworth, London. 
- Gomaa NA. (2004): Ultrasonographic examination of cardiovascular system in dogs. M.V.Sc. Thesis in veterinary internal medicine. Tanta University, Kafr Elshiekh branch

- Goodwin JK and Miller MW (1997): Infective endocarditis. In August JR ed. Consultations in feline internal medicine III. Philadelphia, WB Saunders; 273-278.

- Heffner JE (1979): Extracardiac manifestations of bacterial endocarditis. West J. Med; 131:85-91.

- Kelly, WR (1984):"Veterinary Clinical Diagnosis" 3rd ed .Bailliere Tindall, London, U. K.

- Kim JH Wiseman A and Kisslo J (1989):" Echocardiographic detection and clinical significance of left atrial vegetations in active infective endocarditis" Am J Cardiol; 64: 950-956.

- Kittleson MD and Kienle $R$ (1998): Small animal cardiolovascular medicine. St. Louis, Mo: Mosby; 104-412

- Lombard EW and Buergelt CD (1983): Vegetative bacterial endocarditis in dogs; echocardiography diagnosis and clinical signs. J. Small Animal Practice; 24(6): 325-339.

- Lombard CW and Buergelt CD (1993): Vegetative bacterial endocarditis in dogs; echocardiographic diagnosis and clinical signs. J Small Anim Pract; 24: 325-332

- MacDonald KA, Chomel BB, Kittleson MD, Kasten RW, Thomas WP, Pesavento $\boldsymbol{P}$. (2004): A prospective study of canine infective endocarditis in northern California (1999-2001): emergence of Bartonella as a prevalent etiologic agent. J. Vet Intern Med;18(1):56-64.

- Macdonald KA (2010): Infective endocarditis in dogs: diagnosis and therapy. Vet Clin North Am Small Anim Pract; 40(4):665-684

- McGavin M D; Cartlon WW and Zachary JF(2004): Special Veterinary Pathology"Ed. Mosby, Inc, Missouri, U.S.A, 2001. 
- Means Jr RT (2000): The anemia of infection. Best Practice and Research Clinical Hematology. 13(2):151-161.

- Miller MW; Fox PR and Saunders AB (2004): Pathologic and clinical features of infectious endocarditis. Journal of Veterinary Cardiology, 6(2): 35-43.

- Mylonakis E and Calderwood S B (2001): Infective endocarditis in adults. N Engl J Med; 345: 1318-1330.

- Nicolau DP; Tessier PR; Nightingalec CH and Quintiliani R (1996): Influence of ticlopidine on the development of experimental Staphylococcus aureus endocarditis. International Journal of Antimicrobial Agents; (7): 271-274.

- Norman TJ and Baily MA (1997): Statistical Methods in Biology. 3rd. Cambridge University Press.

- Pauksen K; Elfman L; Ulfgren AK and Venge P (1994): Serum levels of granulocyte-colony stimulating factor (G-CSF) in bacterial and viral infections, and in atypical pneumonia. Br. J. Haematol; 88(2):256-60.

- Peddle G and Sleeper MM (2007): Canine bacterial endocarditis: a review. J. Am. Anim. Hosp. Assoc; 43(5):258-263.

- Sisson D and Thomas WP (1984): Endocarditis of the aortic valve in the dog. J. Am. Vet. Med. Assoc; 184: 570-578.

- Sykes EJ, Kittleson DM, Chomel BB, MacDonald AK and Pesavento AP (2006): Clinicopathologic findings and outcome in dogs with infective endocarditis71 cases(1992-2005).JAVMA;228(11):1735-1747.

- Thiene $G$ and Basso $C$ (2006): Pathology and pathogenesis of infective endocarditis in native heart valves. Cardiovasc. Pathol; 15:256-263.

- Wyllie DH, Bowler IC, Petot E (2004): Relation between lymphopenia and bacteremia in UK adults with medical emergencies. J. Clinic. Pathol; 57:950-955. 


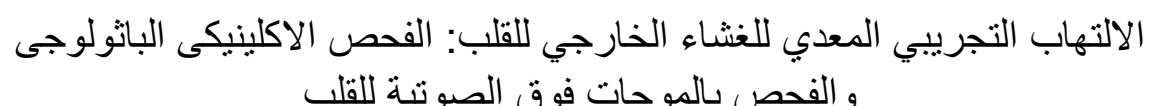

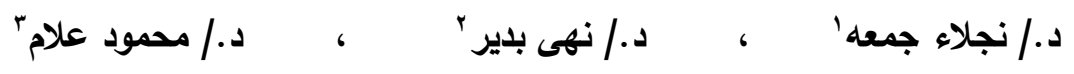

$$
\begin{aligned}
& \text { ' قسم طب الحيوان-كليه الطب البيطري - جامعه كفر الثيخّ } \\
& \text { قسم طب الحيوان - كليه الطب البيطري - جامعه دمنهور } \\
& \text { r قسم طب الحيوان والأمراض المعدية- كليه الطب البيطري- جامعه مدينه السادات }
\end{aligned}
$$

أجريت هذه الدراسة على · ا كلاب تعرضوا تجريبيا إلى التهاب الغثاء القلبي الجرثومي.

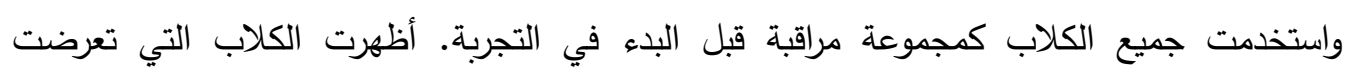
لالتهاب الغشاء القلبي مجموعة واسعة من الأعراض الإكلينيكية بما في ذلك الحمى ، وفقدان الثهية، لإنهاء

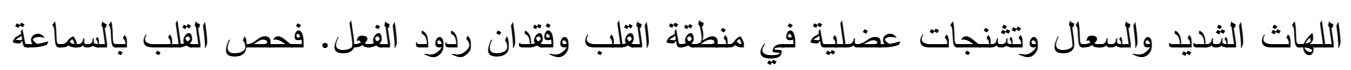
كثف عن وجود لغط صمامي. وأظهر الفحص الباثولوجى للدم عن زيادة في نسبه كلا من الكريات البيضاء وحجم الخلية المعبأة والخلايا اللمفاوية وكذلك انخفاض فى نسبه الخلايا الليهفاوية والهيموجلوبين وعدد كرات الدم الحمراء. وأظهر تخطيط صدى القلب ثنائي الأبعاد عن هيكل عقدي

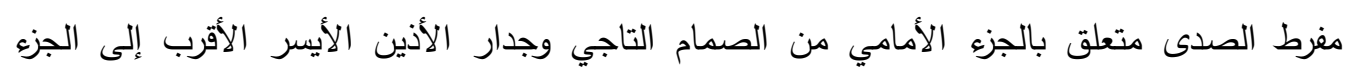

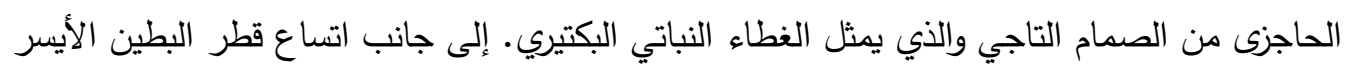

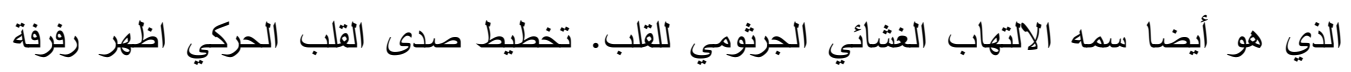
الجزء الأمامي للصمام التاجي أثثاء انبساط القلب وكذلك الإغلاق المبكر للصمام التاجي وهى علامة التهاب مميزة للالتهاب الغثاء الداخلي القلبي. وقد أظهرت الصفة التشريحية للقلب عن وجود كتل مثل القرنبيط التي قللت إلى حد كبير من حجم فتحة صمام القلب التاجي في بعض الحالات. بالإضافة إلى الفحص النسيجي الذي كثف عن وجود التهاب حاد بصمام القلب، انسداد شرايين القلب والمستعمرات البكترية الهدف من التجربة: التحقق من التغيرات المرضية في المراحل المبكرة المرتبطة بالتهاب الغشاء الداخلي 